\title{
Combined effect of irradiation and frozen storage on survival of viable bacteria and inoculated Escherichia coli in chicken
}

\author{
Wellington Torgby-Tetteh ${ }^{1,}$, , Abraham Adu-Gyamfi ${ }^{1}$, Bernard Tawiah Odai ${ }^{1}$, Victoria Appiah ${ }^{2}$ \\ ${ }^{1}$ Radiation Technology Centre, Biotechnology and Nuclear Agriculture Research Institute, Ghana Atomic Energy Commission, Ghana \\ ${ }^{2}$ Department of Nuclear Agriculture and Radiation Processing, School of Nuclear and Allied Sciences, University of Ghana, Ghana
}

\section{Email address:}

wtorgbytetteh@yahoo.com (W. Torgby-Tetteh), adugyamfi21@yahoo.com (A. Adu-Gyamfi), bernardtodai@gmail.com (B. T. Odai), vicappiah@yahoo.com (V. Appiah)

\section{To cite this article:}

Wellington Torgby-Tetteh, Abraham Adu-Gyamfi, Bernard Tawiah Odai, Victoria Appiah. Combined Effect of Irradiation and Frozen Storage on Survival of Viable Bacteria and Inoculated Escherichia Coli in Chicken. Journal of Food and Nutrition Sciences.

Vol. 2, No. 3, 2014, pp. 53-57. doi: 10.11648/j.jfns.20140203.11

\begin{abstract}
Combined effect of irradiation and frozen storage on viable bacteria and inoculated Eschericia coli in chicken was investigated. Samples of uninoculated chicken and samples of chicken inoculated with $E$. coli were irradiated using a Co-60 source at doses of $0,2,4,6$ and $8 \mathrm{kGy}$ and stored for $0,7,14,21,28,35,42,49$ and 56 days at $-18^{0} \mathrm{C}$. Samples were analyzed each week to enumerate surviving viable bacteria and $E$. coli. Irradiation doses of $2,4,6$, and $8 \mathrm{kGy}$ respectively reduced the population of viable bacteria in the uninoculated chicken by 2.06, 2.96, 3.91 and 4.21 log cycles. Storage for 56 days reduced populations of viable bacteria by approximately $2 \log$ cycles for all irradiated uninoculated samples. Dose of $2 \mathrm{kGy}$ reduced the population of $E$. coli in the unirradiated sample by $2.69 \log$ cycles and 4, 6, $8 \mathrm{kGy}$ reduced the population by $>7 \log$ cycles. Storage for 56 days reduced the population of E. coli by 4.07 and $>3.52 \log$ cycles respectively in the unirradiated and irradiated ( $2 \mathrm{kGy}$ ) samples. Irradiation doses of 4 to $8 \mathrm{kGy}$ in combination with frozen storage were effective in reducing the populations of viable indigenous bacteria in addition to eliminating inoculated E. coli from chicken thus extending the shelf life and improving the hygienic quality.
\end{abstract}

Keywords: Chicken, Gamma Irradiation, Frozen Storage, Viable Bacteria, E. coli

\section{Introduction}

Chicken is one of the most important sources of animal protein but it is frequently contaminated by spoilage and pathogenic microorganisms. The presence of these organisms on chicken presents both food security and safety challenges [1, 2]. Meat and poultry related pathogenic infections account for 2.5 to 2.9 million illnesses and 1,000 to 1,200 deaths in the USA, where records are available [3, 4].

Various methods have been employed for controlling spoilage and pathogenic microorganisms in fresh poultry. These include the use of chemicals such as chlorine, hydrogen peroxide, organic acids, antibiotics; and methods such as pasteurization, chilling, freezing and irradiation. There are however limitations in using some of these methods. The use of chemicals deposit residues and cause discolouration whiles heat causes partial cooking and deterioration in the sensory properties of poultry. The combination of different methods of food preservation should be explored as an alternative in the food industry, for example, the use of vacuum packing, gamma radiation, refrigeration and freezing. Preservation methods to maintain the quality and safety of meat for a longer period are needed.

The use of ionizing radiation however has been demonstrated to be safe, environmentally clean and effective in reducing or eliminating various pathogens in fish, red meat and poultry $[1,5,6,7,8,9,10]$. Food irradiation, a non-thermal process, is being used more frequently as a useful and effective means of decontamination to increase the food safety and to extend shelf-life of a wide range of foods without compromising sensory and nutritional quality $[10,11,12,13,14,15]$. The process maintains freshness and quality, while destroying spoilage bacteria and reducing pathogenic bacteria to nondetectable levels. The absence of spoilage bacteria 
increases product shelf life. Irradiation of food up to an overall dose of $10 \mathrm{kGy}$ is accepted in several countries for commercial food processing [16].

The process can be employed as an additional food safety tool to complement other food safety technologies. According to [17] interest in radiation processing is increasing because of persistently high food losses (infestation, contamination) and mounting concern over foodborne diseases. Also foodborne diseases pose a widespread threat to human health and are an important cause of reduced economic activity even in advanced countries which have modern food processing and distribution systems [17]. The effectiveness of the process however depends on several factors, such as packaging, storage temperature, and the irradiation dose employed. As a technology, it can be combined with other processes to enhance the safety of minimally processed foods $[17,18]$. The objective of this study was therefore to investigate the combined effect of irradiation and frozen storage on the survival of viable bacteria and inoculated Escherichia coli in chicken.

\section{Materials and Methods}

\subsection{Samples and Experimental Design}

Fresh samples of chicken thigh used for the study were obtained from a retail outlet in Accra. A two factor randomized complete block experimental design representing five doses $(0$, 2, 4, 6 and $8 \mathrm{kGy})$ and nine storage times $(0,7,14,21,28,35$, 42, 49 and 56 days) with three replicates was used for the study. Samples of chicken thighs were randomly assigned treatments indicated by the design.

\subsection{Uninoculated Pack Experiment}

Uninoculated samples were heat-sealed in polyethylene and stored at $-18^{\circ} \mathrm{C}$ for 24 hours prior to irradiation. After irradiation, both the control and irradiated samples were stored in a freezer at $-18^{\circ} \mathrm{C}$ for $0,7,14,21,28,35,42,49$ and 56 days.

\subsection{Challenge Testing Experiment}

A pure culture of the test isolate (Escherichia coli,) used for the study was isolated from chicken samples. The culture was stored on Nutrient Agar (Oxoid, U.K,) at 3-5 ${ }^{\circ}$, before it was activated by incubation on Eosin Methylene Blue Agar (Oxoid, U.K,) at $37^{\circ} \mathrm{C}$ for 24 hours and used for preparation of inocula. The inocula were standardized to a concentration of $10^{7} \mathrm{cfu} / \mathrm{ml}$ by the method of serial dilution. A $1 \mathrm{ml}$ suspension of the $E$. coli isolate was aseptically added to $10 \mathrm{~g}$ portions of chicken samples in polyethylene bags. The polyethylene bags were heat-sealed and handmassaged for $1 \mathrm{~min}$ to ensure even distribution of the inocula. The samples were stored at $-18^{\circ} \mathrm{C}$ for 24 hours to enable the microorganisms to adjust. After irradiation, both the control and irradiated samples were stored in a freezer at $-18^{0} \mathrm{C}$ for $0,7,14,21,28,35,42,49$ and 56 days.

\subsection{Irradiation of Samples}

Irradiation of uninoculated and inoculated chicken thigh samples was carried out at the Gamma Irradiation Facility of the Ghana Atomic Energy Commission using a 60Cobalt source (SLL-02, Hungary) at a dose rate of $1.1275 \mathrm{kGy} / \mathrm{h}$. Ice packs were arranged around the samples to maintain the temperature required during irradiation. The absorbed dose was determined by using Fricke's dosimetry.

\subsection{Estimation of Viable Bacteria in Uninoculated Samples}

Each $10 \mathrm{~g}$ uninoculated sample was blended with $90 \mathrm{ml}$ diluent $(0.1 \%$ peptone $+0.5 \mathrm{NaCl})$ for 90 min in a Waring Blender and stirred on a mechanical shaker (Junior Orbit Shaker, Lab-Line Instruments, United States of America) for $30 \mathrm{~min}$. Serial dilutions were made up to 109 and $1 \mathrm{ml}$ aliquots were pour-plated in triplicate on Plate count agar (Oxoid, UK). Samples were incubated at 37 o C for 48 hours.

\subsection{Estimation of E. Coli Count in Inoculated Samples}

Each $10 \mathrm{~g}$ inoculated sample was shaken with $90 \mathrm{ml}$ diluent $(0.1 \%$ peptone $+0.5 \mathrm{NaCl})$ on a mechanical shaker (Junior Orbit Shaker, Lab-Line Instruments, United States of America) for $30 \mathrm{~min}$ to ensure that the inoculum is dispersed. Serial dilutions were then prepared up to 108 . The diluted samples were pour-plated in triplicate on Eosin Methylene Blue Agar (Oxoid, UK). Samples were incubated at $37^{\circ} \mathrm{C}$ for 48 hours.

\subsection{Data Analysis}

The microbial counts $(\mathrm{cfu} / \mathrm{g})$ were transformed into logarithms $(\log 10)$ and the data subjected to analysis. Microbial data were analyzed with SPSS Version 16 for Windows.

\section{Results}

\subsection{Combined Effect of Irradiation and Frozen Storage on Total Viable Bacteria in Chicken}

The effect of irradiation on viable bacteria (VB) in chicken during frozen storage is shown in Table 1. Irradiation doses of $2,4,6$, and $8 \mathrm{kGy}$ respectively reduced the VB of the unirradiated sample by $2.06,2.96,3.91$ and $4.21 \log$ cycles. The period of frozen storage further reduced the VB of all the irradiated samples gradually by approximately $2 \log$ cycles over the 56 days of storage. Whiles the unirradiated sample had a total viable count of $4.93 \log _{10} \mathrm{cfu} / \mathrm{g}$ at the end of the storage period, no viable bacteria was detected in sample irradiated at $8 \mathrm{kGy}$.

\subsection{Combined Effect of Irradiation and Frozen Storage on Inoculated E. coli in Chicken}

The effect of irradiation on the population of E. coli in frozen chicken during storage is shown in Table 2. The 
population of $E$. coli gradually decreased with increases in both the irradiation dose and period of frozen storage. Whiles a dose of $2 \mathrm{kGy}$ reduced the population of $E$. coli by $2.69 \log$ cycles in the unirradiated sample, doses of 4,6 and $8 \mathrm{kGy}$ reduced the population by $>7 \mathrm{log}$ cycles to undetectable levels. The results also indicated that the 56day frozen storage further reduced the population of $E$ coli by 4.07 and $>3.52 \log$ cycles respectively in the unirradiated and irradiated ( $2 \mathrm{kGy}$ ) samples.

\section{Discussion}

\subsection{Combined Effect of Irradiation and Frozen Storage on Total Viable Bacteria in Chicken}

The results of this study have shown that irradiation is very effective in reducing the population of viable bacteria on fresh chicken. Irradiation doses of 2 to $8 \mathrm{kGy}$ resulted in approximately 2 to $4 \log$ cycle reductions of viable bacteria on chicken. This observation confirms irradiation as one of the best methods to ensure safety of frozen poultry as has been also observed in other studies $[19,20,21]$. The action of irradiation on microorganisms has been shown to occur via radical molecules created when high-energy particles split water molecules within surrounding or within bacteria. These molecules are highly reactive and very short-lived, so short-lived that they cannot be detected in food almost immediately after it has been irradiated. These radicals damage cellular and biochemical structures such as proteins, cell membranes and nucleic acid strands [22, 23].

This study also showed that frozen storage at $-18^{0} \mathrm{C}$ further reduced the population of viable bacteria in chicken by approximately 1 to $3 \log$ cycles over the 56 days after irradiation at doses of 2 to $8 \mathrm{kGy}$. The use of irradiation combined with refrigeration has been reported [8, 7, 24, 25]. It is important to note that the response of bacteria to ionising radiation varies according to their D10 values [26, 27]. Thus, any surviving bacteria with psychrotrophic properties will multiply and reduce the shelf life of irradiated chicken if the storage temperature is not kept below $5^{\circ} \mathrm{C}$. This observation underlies the need to combine irradiation and frozen storage to achieve maximum shelf life extension of irradiated chicken.

Table 1. Combined effect of irradiation and frozen storage $\left(-18^{\circ} \mathrm{C}\right)$ on survival of viable bacteria in chicken.

\begin{tabular}{|c|c|c|c|c|c|c|c|c|c|}
\hline \multirow{2}{*}{$\begin{array}{c}\text { DOSE } \\
(\mathrm{kGy})\end{array}$} & \multicolumn{9}{|c|}{ STORAGE TIME (DAYS) } \\
\hline & $\mathbf{0}$ & 7 & 14 & 21 & 28 & 35 & 42 & 49 & 56 \\
\hline 0 & $7.14 \pm 0.03$ & $6.17 \pm 0.03$ & $6.14 \pm 0.03$ & $5.94 \pm 0.02$ & $5.86 \pm 0.06$ & $5.78 \pm 0.08$ & $5.65 \pm 0.06$ & $5.53 \pm 0.02$ & $4.93 \pm 0.035$ \\
\hline 2 & $5.08 \pm 0.05$ & $5.01 \pm 0.03$ & $5.01 \pm 0.01$ & $4.97 \pm 0.03$ & $4.78 \pm 0.04$ & $4.65 \pm 0.04$ & $4.62 \pm 0.02$ & $4.52 \pm 0.04$ & $3.88 \pm 0.043$ \\
\hline 4 & $4.18 \pm 0.02$ & $4.14 \pm 0.03$ & $3.93 \pm 0.05$ & $3.92 \pm 0.02$ & $3.87 \pm 0.05$ & $3.73 \pm 0.05$ & $3.55 \pm 0.5$ & $3.52 \pm 0.03$ & $3.50 \pm 0.040$ \\
\hline 6 & $3.23 \pm 0.02$ & $3.23 \pm 0.02$ & $3.18 \pm 0.03$ & $3.13 \pm 0.02$ & $2.89 \pm 0.04$ & $2.77 \pm 0.06$ & $2.73 \pm 0.03$ & $2.68 \pm 0.04$ & $2.63 \pm 0.10$ \\
\hline 8 & $2.93 \pm 0.03$ & $2.92 \pm 0.02$ & $2.90 \pm 0.02$ & $2.87 \pm 0.03$ & $2.74 \pm 0.05$ & $2.68 \pm 0.02$ & $2.65 \pm 0.03$ & $2.56 \pm 0.06$ & $<1.00$ \\
\hline
\end{tabular}

Mean count $[\log 10 \mathrm{cfu} / \mathrm{g}] \pm \mathrm{SD}(\mathrm{n}=3)$; detection limit $=1.00$

\subsection{Combined Effect of Irradiation and Frozen Storage on Inoculated E. coli in Chicken}

The capacity of gamma radiation to eliminate a potential pathogen such as $E$. coli from frozen chicken during storage has been demonstrated by this study since doses of 4 to $8 \mathrm{kGy}$ completely eliminated viable bacteria to undetectable levels. This finding supports an earlier study that reported the susceptibility of E. coli to gamma radiation $(\mathrm{D} 10=0.32 \mathrm{kGy})$ in chicken under frozen conditions [1]. It is noteworthy to emphasize that whiles a dose of $2 \mathrm{kGy}$ reduced the population of $E$. coli by $>2 \log$ cycles, reductions of $>7 \mathrm{log}$ cycles were achieved in combination with frozen storage. Similarly, [7] reported a decrease in the populations of $E$. coli after irradiation and refrigerated storage. An ionizing radiation of $<3.0 \mathrm{kGy}$ has been reported to significantly lower the population of the most common enteric pathogens, such as, Campylobacter jejuni, E. coli, S. aureus, Salmonella spp., $L$. monocytogenes and Aeromonas hydrophila [28].

This study has revealed the need for combination treatment of irradiation and frozen storage to reduce or eliminate microbial populations in chicken. Irradiation doses of 4 to $8 \mathrm{kGy}$ in combination with frozen storage were effective in reducing the populations of viable indigenous bacteria in addition to eliminating inoculated $E$. coli from chicken. Combination treatments will enable the use of low irradiation doses that could preserve flavor and texture of poultry products. Irradiation in combination with frozen storage can therefore be an effective way of reducing spoilage bacteria and also eliminating enteric pathogens associated with poultry products, extending the shelf life and improving the hygienic quality.

Table 2. Combined effect of irradiation and frozen storage $\left(-18^{\circ} \mathrm{C}\right)$ on survival of Escherichia coli in chicken.

\begin{tabular}{llllllllll}
\hline $\begin{array}{l}\text { DOSE } \\
\text { (kGy) }\end{array}$ & $\mathbf{0}$ & $\mathbf{7}$ & $\mathbf{1 4}$ & $\mathbf{2 1}$ & $\mathbf{2 8}$ & $\mathbf{3 5}$ & $\mathbf{4 2}$ & $\mathbf{4 9}$ & $\mathbf{5 6}$ \\
\hline 0 & $7.21 \pm 0.02$ & $6.21 \pm 0.04$ & $5.55 \pm 0.06$ & $5.52 \pm 0.01$ & $4.86 \pm 0.3$ & $4.23 \pm 0.02$ & $3.75 \pm 0.03$ & $3.29 \pm 0.02$ & $3.14 \pm 0.01$ \\
2 & $4.52 \pm 0.07$ & $4.12 \pm 0.02$ & $4.02 \pm 0.02$ & $3.50 \pm 0.03$ & $2.78 \pm 0.06$ & $2.68 \pm 0.04$ & $2.62 \pm 0.03$ & $2.52 \pm 0.07$ & $<1.00$ \\
4 & $<1.00$ & $<1.00$ & $<1.00$ & $<1.00$ & $<1.00$ & $<1.00$ & $<1.00$ & $<1.00$ & $<1.00$ \\
6 & $<1.00$ & $<1.00$ & $<1.00$ & $<1.00$ & $<1.00$ & $<1.00$ & $<1.00$ & $<1.00$ & $<1.00$ \\
8 & $<1.00$ & $<1.00$ & $<1.00$ & $<1.00$ & $<1.00$ & $<1.00$ & $<1.00$ & $<1.00$ & $<1.00$ \\
\hline
\end{tabular}

Mean count $[\log 10 \mathrm{cfu} / \mathrm{g}] \pm \mathrm{SD}(\mathrm{n}=3)$; detection limit $=1.00$ 


\section{Conclusions}

Gamma irradiation is effective in reducing viable bacteria and eliminating potential pathogens such as $E$. coli from fresh chicken. The combination of irradiation and frozen storage enhanced the hygienic quality of the chicken. Irradiation doses of 4 to $8 \mathrm{kGy}$ and frozen storage could be suitable for reducing microbial contamination and extending the shelf-life of chicken.

\section{Acknowledgement}

The authors wish to express deep appreciation to the Director General of the Ghana Atomic Energy Commission (GAEC), the Director of the Biotechnology and Nuclear Agriculture Research Institute and the staff of the division of the Radiation Technology Centre.

\section{References}

[1] Adu-Gyamfi, A., Torgby-Tetteh, W., and Appiah, V. (2012) Microbiological Quality of Chicken Sold in Accra and Determination of D10-Value of E. coli, Food and Nutrition Sciences, 2012, 3, 693-698

[2] Aymerich, T., Picouet, P. A., Monfort, J. M. (2008) Decontamination technologies for meat products. Meat Science, $78,114-129$

[3] Mead, P. S., L. Slutsker, V. Dietz, L. F. McCaig, J. S. Bresee, C. Shapiro, P. M. Griffin, and R. V. Tauxe. (1999) "FoodRelated Illness and Death in the United States," Emerging Infectious Diseases, Vol. 5, No. 5, pp. 607-25.

[4] USDA, (1996) U.S. Department of Agriculture, Food Safety and Inspection Service. Supplement - Final Regulatory Impact Assessment for Docket No. 93-016F, Pathogen Reduction; Hazard Analysis and Critical Control Point (HACCP) Systems: Final Rule,” Federal Register. Vol. 61, No. 144, July 25, 1996, pp. 38945-89.

[5] Adu-Gyamfi, A., Nketsia-Tabiri, J and Apea Bah, F. (2008). Radiosensitivities of bacterial isolates on minced chicken and poached chicken meal and their elimination 77, (2):174178

[6] Thayer, D. W. (1993). Extending shelf life of poultry and red meat by irradiation processing, Journal of Food Protection 56(10): 831-833

[7] Spoto, M. H. F., Gallo, C. R., Alcarde, A. R., Gungel, Silvia do Amaral. M., Blumer, L., Walder, M. M. and Domarco, R. E. (2000). Gamma irradiation in the control of pathogenic bacteria in refrigerated chicken meat. Scientia Agricola, 57(3): 389-394.

[8] Oraei, M., Motalebi, A. A., Hoseini, E and Javans, S. (2010). Effect of gamma irradiation and frozen storage on the microbial quality of Rainbow trout (Oncorhynchus mykiss) fillet. Iranian Journal of Fisheries Sciences, 10(1), 76-84

[9] Nunticha, T., Pattama, R,. and Pongtep W. (2011). Radiation resistances and decontamination of common pathogenic bacteria contaminated in white scar oyster (Crassostrea belcheri) in Thailand. Radiation Physics and Chemistry, 80, $828-832$

[10] Cutrubinis C. D., Savua, D., Elisabeta S. C., Mihaia R., Secub Ponatta C., (2007). Preliminary Study of on detection of irradiated foodstuffs from the Romanian market., Radiation Physics and Chemistry, 76, 1450-1454

[11] Farkas, J., 2006. Irradiation for better foods. Trends in Food Science \& Technology 17, 148-152.

[12] Kim, H. J., Ham, J. S., Lee, J. W., Kim, K., Ha, S. D., Jo, C., 2010. Effects of gamma and electron beam irradiation on the survival of pathogens inoculated into sliced and pizza cheeses. Radiation Physics and Chemistry 79, 731-734.

[13] Kanatt, S.R., Chander, R., Sharma, A.: Effect of radiation processing on the quality of chilled meat products. Meat Sci., 2005; 69: 269-275.

[14] Yoon K. S. (2003) Effect of gamma irradiation on the texture and microstructure of chicken meat, Meat science, 63, 273-277

[15] Jo, C., Lee, N.Y., Kang, H.J., Shin, D.H., Byun, M.W. (2004). Inactivation of foodborne pathogens in marinated beef rib by ionizing radiation. Food Microbiol. 21: 543-548

[16] Lacroix, M., Quattara, B. (2000). Combined industrial processes with irradiation to assure innocuity and preservation of food products-a review. Food Res Int. 33(9), 719-724.

[17] International Consultative Group on Food Irradiation (1999). Irradiation and Trade in food and Agricultural Products, ICGFI Secretariat, ICGFI Policy Document.

[18] Farkas, J. (1998). Microbiology safety of foods, International Journal of Microbiology 9:1-15

[19] Clark, P. J (2006). Food irradiation update, Food Technology Magazine, 60(10), 73.

[20] Diehl, J.F. (1995). Safety of Irradiated Foods (Second Edition). Marcel Dekker, Inc., New York

[21] Smith, J. S. and Pillai, S. (2004) Irradiation and Food Safety. An IFT Scientific Status Summary, Food Technology. 58 (11): $48-55$

[22] Niemira, B.A. and C.H. Sommers (2006), New Applications in Food Irradiation. In D.R. Heldman, ed., Encyclopedia of Agricultural, Food and Biological Engineering, Dekker Encyclopedias, Taylor \& Francis Publishers.

[23] Diehl, J. F. (1990) Biological Effects of Ionizing Radiation, in: Diehl, J. F. (Eds)., Safety of Irradiated Foods, Marcel Dek-ker Inc., New York, 1990, pp. 95-136.

[24] Gomes, H. A., Nepomuceno da Silva, E., Cardello, H. M. A. B., Cipolli, K. M. V. B. (2003). Effect of gamma radiation on refrigerated mechanically deboned chicken meat quality, Meat Science, 65, 919-926

[25] Yazdia F. T. and Joukib M. (2012). Gamma irradiation effects on microbial decontamination of ostrich meat, Scientific Journal of Microbiology 1(5) 119-125

[26] Thayer, D. W. (2000). Sources of Variation and Uncertainty in the Estimation of Radiation D-10 Values for Foodborne Pathogens, ORACBA News, Vol 4 No.5 
[27] Monk, J. D., Beuchat, L. R. and Doyle, M. P. (1995). Irradiation Inactivation of Food-Borne Microorganisms, Journal of Food Protection, Vol. 58, No. 2, 1995, pp. 197208
[28] Thayer, D.W. (1995). Use of irradiation to kill enteric pathogens on meat and poultry. Journal of Food Safety, 15: 181-192. 